\title{
Performance of Simple and Complex Computerized Learning Tasks: Division of Attention vs. Division of Labor
}

\author{
Joseph Klein \\ School of Education, Bar Ilan University, Ramat Gan, Israel
}

kleini@mail.biu.ac.il

\begin{abstract}
The need to divide attention in order to deal with information flow ing in from a number of sources is observable in many work settings. Although most people can perform several simple activities concurrently, such as eating and watching television (Sharon, 1997), making simultaneous decisions is difficult (Pashler \& Johnston, 1998). For the majority, task overload causes errors in performance (Girard, 2007), a decline in the quality of treatment (Ruthruff et al., 2001), and longer reaction time (Levy et al., 2006). The few who cope efficiently under such circumstances employ different cognitive strategies.

Teamwork is one way of managing multiple demands. Group work makes it possible to deal with larger amounts of information and to generate a variety of ideas as well as to minimize faulty conclusions. On the other hand, individuals make speedier and better decisions, and are not subject to the tensions of interplay (Davis and Toseland, 1987). The literature offers little information on methods of testing the conditions under which tasks should be handled by one agent or a team.

The educational project described here was conducted comparing efficiency of performance of a series of tasks by individuals and small groups. 116 participants, ranging in age from high school level through holders of Masters' degrees, 58 women and the same number of men, were presented with a computer game based on educational software. Participants were instructed to manipulate a tracker by means of the keyboard in order to contact a target moving randomly on the screen. The game was arranged in five levels of difficulty. A comparison was made of the speed in which objectives were attained when performed individually and when divided among groups of two to four partners, controlling for the type of coordination, cognitive style and additional background variables. Cases of expedient and inexpedient division of labor were identified, as were factors affecting feasibility. Among the latter were the size of the simultaneous task load, complexity level, number of participants, and the intensity of coordination required among them.
\end{abstract}

The optimal number of partners depended on the type of action prescribed. When the demand for division of attention was not onerous, evidence indicated a preference for a single participant who

Material published as part of this publication, either on-line or in print, is copy righted by the Informing Science Institute. Permission to make digital or paper copy of part or all of these works for personal or classroom use is granted without fee provided that the copies are not made or distributed for profit or commercial advantage AND that copies 1) bear this notice in full and 2) give the full citation on the first page. It is permissible to abstract these works so long as cred it is given. To copy in all other cases or to republish or to post on a server or to redistribute to lists requires specific permission and payment of a fee. Contact Publisher@InformingScience.org to request redistribution permission. did not have to deal with the demands of interpersonal coordination. With a slight increase in complexity, two or three partners were more successful than an individual performer. As the game plan became even more intricate, three partners had the advantage. In all trials, a team of four was consistently less successful. The results suggest that in a complex format, the problem of divided attention was a more dominant factor 
than the need for coordination between two or three players. Cooperation became a major factor again when groups of four were activated.

The decision with regard to cooperative or individual activity must also take expected achievement into account. The goal set for the task tested in this study was defined as reaching the target in minimal elapsed time. Under conditions in which individuals attain the goal faster than a group, there is no valid reason for compelling them to take on partners.

The present paper provides educational administrators and developers of scholastic projects with basic considerations intended to assist in making decisions about the division of roles and functions. Whether two heads are better than one or too many cooks spoil the broth depends both on the relative complexity of the assignment and the nature of the interaction taking place when more than one individual is involved.

Ke ywords: Computerized learning, Performance, Cooperation

\section{References}

Davis, L. V., \& Toseland, R. W. (1987). Group versus individual decision making: An experimental analysis. In R. W. Toseland \& P. H. Ephross (Eds.), Working effectively with administrative groups (pp. 195-110). Binghamton New York: Howorth Press.

Girard, N. (2007). Multitasking: How much is too much? AORN, 85(3), 505-506.

Levy, J., Pashler, H., \& Boer, E (2006). Central interference in driving: Is there any stopping the psychological refractory period? Psychological Science, 17(3), 228-235.

Pashler, H., \& Johnston, J. (1998). Attentional limitation in dual-task performance. In H. Pashler (Ed.), Attention (pp. 155-189). Hove, East Sussex: Tay lor and Francis.

Ruthruff, E., Johnston, J. C., \& Van Selst, M. V. (2001). Why practice reduces dual-task interference. Journal of Experimental Psychology: Human Perception and Performance, 27, 3-21.

Sharon, M. (1997). Divided attention: A study on high organizing abilities. Tel-Aviv, Is rael: Go meh Scientific Publications, Tcherikover Publishers

\section{Biography}

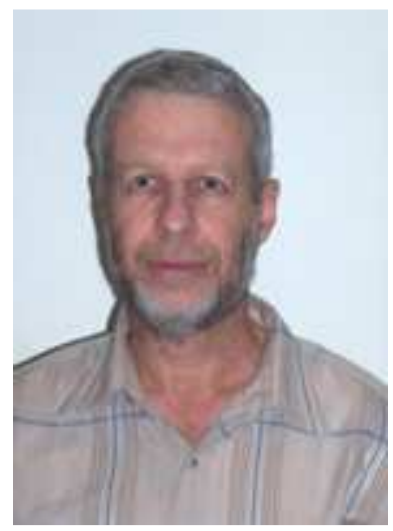

Joseph Klein is the head of the Division of Leadership and Educational Administration at the School of Education, Bar Ilan University, Israel. His research is primarily in the field of the cognitive aspects of decision making and practical implications in education. A few of his recent research projects compared the efficiency of intuitive judgment with computer - assisted decisions (DSS). He and his wife have five children and six grandchildren. 